\title{
MODELLING OF RESISTIVE SENSOR FOR HIGH POWER MICROWAVE PULSE MEASUREMENT OF TE 11 MODE IN CIRCULAR WAVEGUIDE
}

\author{
Ž. Kancleris ${ }^{\mathrm{a}, \mathrm{b}}$, G. Šlekas ${ }^{\mathrm{a}}$, V. Tamošiūnas ${ }^{\mathrm{a}, \mathrm{b}}, \mathrm{M}$. Tamošiūniené ${ }^{\mathrm{a}}$, and M. Dagys ${ }^{\mathrm{a}}$, \\ ${ }^{a}$ Microwave Laboratory, Semiconductor Physics Institute, Center for Physical Sciences and Technology, A. Goštauto 11, \\ LT-01108 Vilnius, Lithuania \\ E-mail: kancleris@pfi.lt \\ ${ }^{\mathrm{b}}$ Faculty of Physics, Vilnius University, Sauletekio 9, LT-10222 Vilnius, Lithuania
}

Received 22 March 2010; revised 1 June 2010; accepted 17 June 2010

\begin{abstract}
Interaction of a semiconductor plate with $\mathrm{TE}_{11}$ wave in a circular waveguide has been analysed for the purpose of optimizing a frequency response of a resistive sensor (RS). The performance of the RS is based on the electron heating effect and it is devoted to high power microwave pulse measurement. The semiconductor plate with contacts on its sidewalls serves as sensing element (SE) of the RS. A three-dimensional finite-difference time-domain method (FDTD) was applied to simulate wave propagation within a circular waveguide segment with the SE which is placed on a wall of the circular waveguide. The electric field distribution, voltage standing wave ratio (VSWR), and the average electric field dependences on frequency have been determined for several sets of dimensions and specific resistances of the SE. The parameters of the optimal SE were found.
\end{abstract}

Keywords: electromagnetic wave, circular waveguide, mode $\mathrm{TE}_{11}$, semiconductor obstacle, resistive sensor

PACS: $41.20 .-\mathrm{q}, 07.50 .-\mathrm{e}$

\section{Introduction}

Pulsed high power microwave (HPM) devices are widely used in various areas of application. The main device being used for the measurement of the HPM pulse power is a semiconductor diode. However, when the diode is used to measure HPM pulses, the initial pulse has to be strongly attenuated and the measurement accuracy decreases [1].

The RS (as an alternative device), performance of which is based on the electron heating effect in semiconductors, has been described in detail in [1]. The SE of the RS was inserted into a rectangular waveguide. Its resistance increases when the electric field of the microwave pulse heats electrons in the SE. By measuring this resistance change, the microwave pulse power in the transmission line is determined.

The certain advantages of the RS compared with the diode were accented in $[1,2]$. The RS can measure HPM pulses directly, produces high output signal, is overload resistant, and demonstrates very good long term stability [1]. The RS has proved to be a very convenient means of diagnostics in microwave electronics, especially for the measurement of short HPM pulses at a low repetition rate [2]. The typical experimental arrangement for such measurements is simple and flexible [2].

The possibility to use a semiconductor obstacle placed on the wall of a circular waveguide as the resistive sensor has been analysed in [3].

Having in mind the drawbacks of the measurement of HPM pulses in facilities employing circular waveguides in the output, the RS, in the circular waveguide operating at $\mathrm{TE}_{01}\left(\mathrm{H}_{01}\right)$ mode whose losses decrease with increasing frequency, has been developed in our previous paper [4]. However, $\mathrm{TE}_{01}$ mode propagating in a circular waveguide is not the lowest one [5]. The lowest $\mathrm{TE}_{11}\left(\mathrm{H}_{11}\right)$ mode is frequently employed in the experiments and it is considered in [6-10].

It was noted in [6] that circular waveguides are widely used in the fabrication of many passive components, in order to implement resonant cavities as well as irises to connect adjacent guides for particle accelerators. Mode coupling in elliptically distorted overmoded circular waveguides has been studied in [7] theoretically and experimentally in order to optimize $\mathrm{TE}_{11}$ mode polarizer for HPM pulses at $70 \mathrm{GHz}$. The frequency performance of $\mathrm{TE}_{11}$ mode circular waveguide 
filters is analysed in [8]. A theoretical analysis employing a method in which electromagnetic fields are represented in the form of transmission equations is presented. In [9], where a high power (50 MW) microwave amplifier is analysed, the collector transforms the cable wave of the plasma into the $\mathrm{TE}_{11}$ wave of the output circular waveguide. The circular iris in a $\mathrm{TE}_{11}$ mode circular waveguide is analysed by Galerkin method in [10]. A comparison between calculated and measured $\mathrm{TE}_{11}$ mode parameters at two frequencies is presented.

Our activities in this paper will be concentrated on the elucidation of the peculiarities of the interaction of the electromagnetic $\mathrm{TE}_{11}$ wave, propagating in the circular waveguide, with the semiconductor plate placed on the waveguide wall. Our task is to find such parameters of the plate that it could serve as the prototype of the SE for the circular waveguide RS.

\section{2. $\mathbf{T E} \mathbf{E}_{11}$ mode in circular waveguide}

The regular $\mathrm{TE}_{11}$ wave has five components: $E_{\varphi}, E_{r}$, $H_{\varphi}, H_{r}$, and $H_{z}$ [5]. Dependences of the amplitudes of the regular wave on the radial $r$ and azimuthal $\varphi$ coordinates can be expressed in the following way [5]:

$$
\begin{gathered}
E_{r}(r, \varphi)=A a \frac{J_{1}\left(\chi_{11} r / a\right)}{\chi_{11} r} \cos \varphi, \\
E_{\varphi}(r, \varphi)=-A J_{1}^{\prime}\left(\chi_{11} r / a\right) \sin \varphi, \\
H_{r}(r, z)=-A \frac{\lambda}{\lambda_{w}} \sqrt{\frac{\varepsilon_{0}}{\mu_{0}}} J_{1}^{\prime}\left(\chi_{11} r / a\right) \sin \varphi, \\
H_{\varphi}(r, z)=A a \frac{\lambda}{\lambda_{\mathrm{c}}} \sqrt{\frac{\varepsilon_{0}}{\mu_{0}}} \frac{J_{1}\left(\chi_{11} r / a\right)}{\chi_{11} r} \cos \varphi, \\
H_{z}(r, z)=A \frac{\lambda}{\lambda_{\mathrm{c}}} \sqrt{\frac{\varepsilon_{0}}{\mu_{0}}} J_{1}\left(\chi_{11} r / a\right) \sin \varphi .
\end{gathered}
$$

Here the coefficient $A$ is measured in electric field units and it depends on the power propagating through the waveguide, $\lambda, \lambda_{w}$, and $\lambda_{\mathrm{c}}$ are the wavelength of electromagnetic oscillations in free space, in a waveguide, and the critical wavelength for the $\mathrm{TE}_{11}$ mode, respectively, $\varepsilon_{0}$ and $\mu_{0}$ are the vacuum permittivity and permeability, $J_{1}$ and $J_{1}^{\prime}$ are the first kind and first order Bessel function and its derivative, $\chi_{11}=1.8412$ is the root of $J_{1}^{\prime}: J_{1}^{\prime}\left(\chi_{11}\right)=0$, and $a$ is a radius of the waveguide.

The maximum of radial and azimuthal components of the electromagnetic field is reached in the centre of the waveguide while the axial component of the magnetic field gets its maximum at a metal wall of the circular waveguide.

\section{Resistive sensor in circular waveguide}

The SE is actually a resistor made from $n$-type $\mathrm{Si}$ with two ohmic contacts [1]. The practical realization of the SE for cylindrical waveguide is shown in Fig. 1(a). It is seen that the SE is put on a dielectric. One contact of it is grounded, while the other one is isolated. The same layout of the SE has been used in our previous papers $[3,4]$ where the $\mathrm{RS}$ for $\mathrm{TE}_{01}$ mode has been analysed. Cross-sectional view of the modelled structure in a cylindrical coordinate system is shown in Fig. 1(b). Azimuthal $d$ and radial $h$ dimensions of the $\mathrm{SE}$ are shown in the figure. The length of it in a wave propagation direction is denoted as $l$.

As follows from (1) and (2), amplitudes of the electric field of the regular wave depend on azimuthal angle $\varphi$. The component $E_{r}$ is a maximum at $\varphi=0^{\circ}(1)$, while the component $E_{\varphi}$ is a maximum at $\varphi=90^{\circ}$. Since the average electric field in the SE might be dependent on the angle between it and the polarization plane, the calculations should be performed for the SE placed at different angle $\varphi$ in respect of the polarization plane (see Fig. 1(b)).

Like in [4], the main requirements for $\mathrm{SE}$ can be formulated as follows: first, it should not cause considerable reflection in the waveguide, so the value of VSWR has been set at $<1.2$; second, the RS should be able to measure nanosecond-duration HPM pulses; therefore, the DC resistance of the RS should not exceed 50 $\Omega$; finally, the flat frequency response of the RS in the waveguide's frequency band is preferable.

It is well established that in the limit of a slightly heating electric field the relative resistance change is proportional to the square of electric field [1]. We consider a sensitivity of the RS in the linear region where the output signal is proportional to the pulse power $P$ propagating in the waveguide. Since the resistance change of SE is a quantity indicating the pulse power in the waveguide, it is convenient to define the sensitivity of RS as

$$
\xi=\frac{\Delta R / R}{P}=\frac{\beta^{*}\langle E\rangle^{2}}{P},
$$

where $\beta^{*}$ is a so-called effective warm-electron coefficient [1] and $\langle E\rangle$ is an average amplitude of the electric field in the SE. In general, the effective warm electron coefficient is frequency dependent and it decreases 
(a)

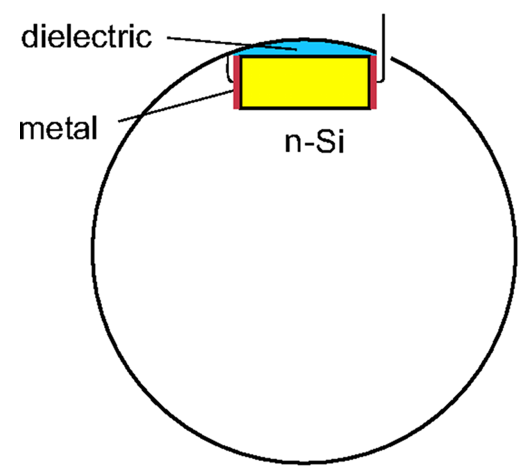

(b)

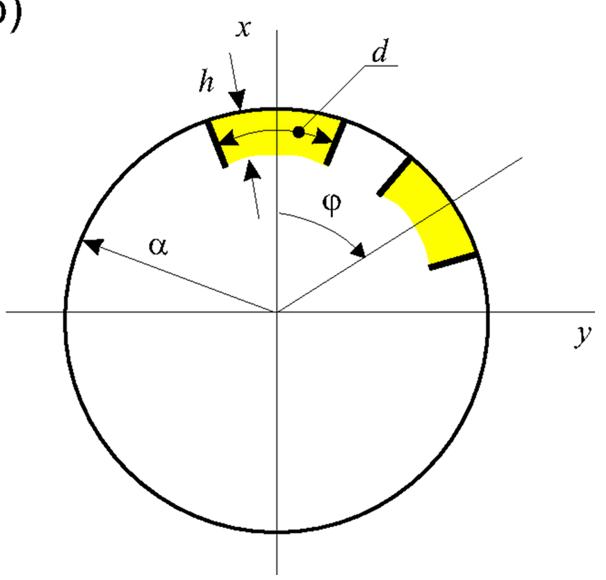

Fig. 1. (a) Practical realization of the SE in the circular waveguide and (b) its model in a cylindrical coordinate system. $\varphi$ in (b) denotes the angle between the centre of the SE and polarization plane.

while the frequency increases. In the present investigation we do not take into account this effect therefore our findings can be used up to and including the $\mathrm{X}$-band where the decrease of $\beta^{*}$ with frequency is less than $3 \%$.

The power transfer by the $\mathrm{TE}_{11}$ mode can by straightforwardly computed by integrating the Poynting vector over cross-sectional area of the waveguide. Inserting the result into (6) one can get the following expression:

$$
\xi=\frac{\beta^{*}}{\pi a^{2} B} \frac{\sqrt{\mu_{0} / \varepsilon_{0}}}{\sqrt{1-\left(\lambda / \lambda_{\mathrm{c}}\right)^{2}}}\left(\frac{\langle E\rangle}{E_{0}}\right)^{2},
$$

describing the sensitivity of RS in the linear region. $E_{0}$ in (7) denotes the maximum of electric field amplitude in the regular $\mathrm{TE}_{11}$ wave in the centre of an empty waveguide and coefficient $B$ is expressed as

$$
B=\left[J_{0}^{2}\left(\chi_{11}\right)+\left(1-\frac{2}{\chi_{11}^{2}}\right) J_{1}^{2}\left(\chi_{11}\right)\right]
$$

The Bessel function values are: $J_{0}\left(\chi_{11}\right)=0.3160$ and $J_{1}\left(\chi_{11}\right)=0.5819$. The average electric field is the only unknown quantity in (7). Thus after determining it, the sensitivity of RS in the linear region can be calculated.

Except $\langle E\rangle$ the only multiplier in (7) that influences the dependence of sensitivity of RS on frequency is the square root appearing in the denominator of the expression. It indicates the fact that even at the same power level transmitted through the waveguide, the electric field strength in it decreases with frequency because of the wave dispersion in the waveguide. This, in turn, leads to the decrease of sensitivity.

Circular waveguides with the $\mathrm{TE}_{11}$ mode are usually employed in the frequency range $\lambda / \lambda_{c}=0.85-0.6$ [11]. From (7) it is easy to get that the sensitivity in this frequency range decreases by a factor of 1.52 . If the av- erage electric field in the SE increases by a factor $\eta=$ 1.23 in the same frequency range (see (7)), it will compensate the decrease of sensitivity due to the wave dispersion in the waveguide. As a result, the RS with flat frequency response will be developed.

Considering this fact and the requirements for the RS formulated above, we performed calculations of the average electric field in the SE with a goal to find the RS with the optimal frequency response. When $\langle E\rangle$ is determined, the dependence of $\Delta R / R$ on $P$ can be calculated in a wider dynamical range of the power transmitted through the waveguide in a similar way as in [4]:

$$
\begin{aligned}
& \frac{\Delta R}{R}= \\
& \frac{1}{2 k_{n}^{*}}\left\{\sqrt{1+\frac{4 k_{n}^{*} \beta^{*}}{\pi a^{2} B}\left(\frac{\langle E\rangle}{E_{0}}\right)^{2} \frac{\sqrt{\mu_{0} / \varepsilon_{0}}}{\sqrt{1-\left(\lambda / \lambda_{\mathrm{c}}\right)^{2}}}}-1\right\},
\end{aligned}
$$

where $k_{n}^{*}$ describes the deviation of $\Delta R / R$ from quadratic dependence. Typical values of $\beta^{*}$ and $k_{n}^{*}$ for $n$-type $\mathrm{Si}$ at a room temperature are collected in [1].

Though the regular $\mathrm{TE}_{11}$ type wave has five electromagnetic field components (see (1)-(5)), the $E_{z}$ component might also appear in a vicinity of the SE. Therefore, to determine the average electric field amplitude in the semiconductor obstacle Maxwell's equations have to be solved computing all six components of the electric and magnetic fields.

We used the FDTD method [12] for the calculation of electromagnetic field components in the structure. Details about the FDTD application for simulation of a wave propagation within a circular waveguide segment with the SE can be found in $[3,4]$. To overcome the singularity at $r=0$ we have followed a method pro- 
(a)

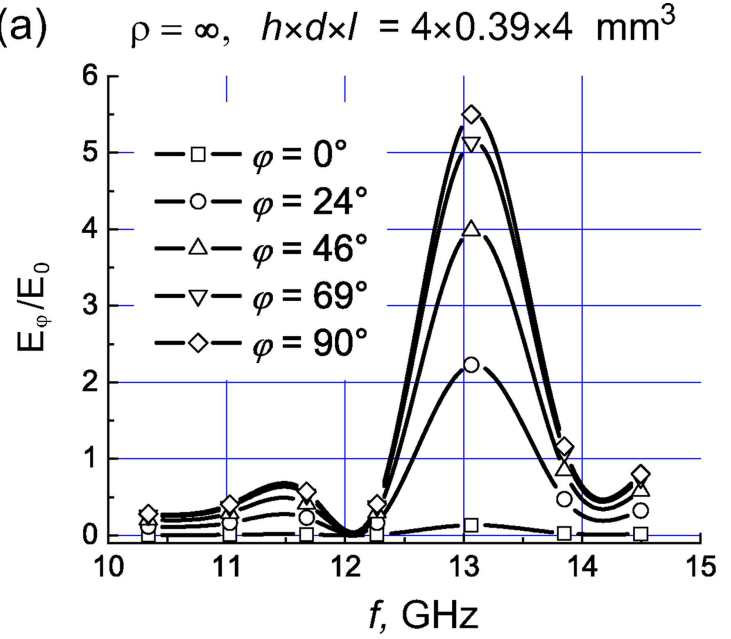

(b)

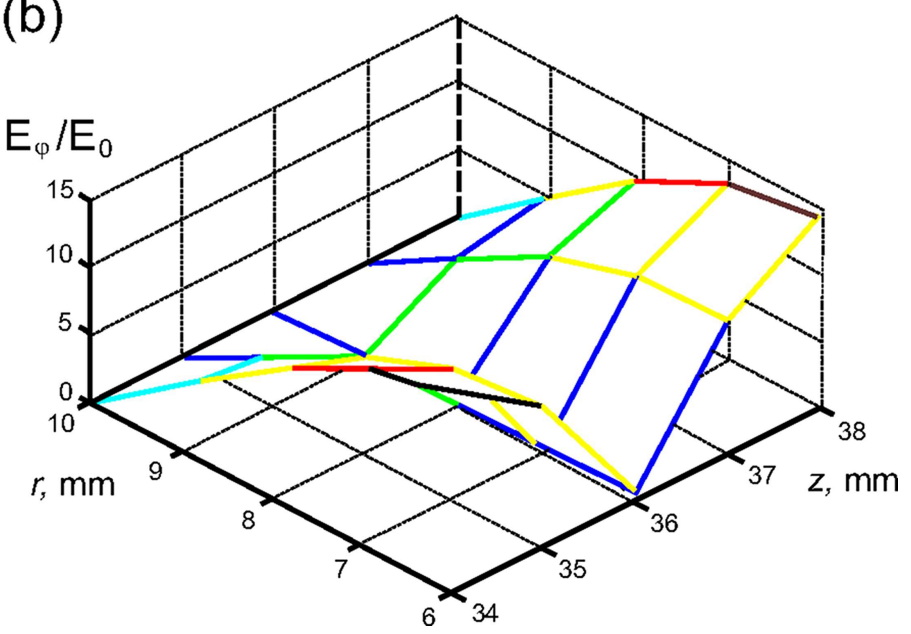

Fig. 2. (a) Average electric field in the dielectric obstacle versus frequency for several polarization angles of the incident wave and (b) distribution of the electric field averaged in $\varphi$ direction within the $\mathrm{SE}$ at the resonance frequency $13.1 \mathrm{GHz}$ and $\varphi=90^{\circ}$. Dimensions of the obstacle are indicated in the figure.

posed in [13] that is based on the use of the Cartesian coordinate system in the vicinity of $r=0$.

Calculations have been performed for a waveguide with the inner radius $a=1 \mathrm{~cm}$. For such radius of the waveguide the critical wavelength for the $\mathrm{TE}_{11}$ mode is $\lambda_{\mathrm{c}}=3.41 \mathrm{~cm}$ that corresponds to the cutoff frequency $f_{c}=8.78 \mathrm{GHz}$. We performed calculations starting from $f_{c} / f=0.85, f=10.3 \mathrm{GHz}$, towards higher frequency. Typical dimensionless size of steps used in calculations were $\Delta z / a=\Delta r / a=0.025, \Delta \varphi=1.406^{\circ}$, $\Delta t \cdot c / a=3 \cdot 10^{-4}$, where $c$ is the velocity of electromagnetic waves in free space.

\section{Modelling results}

In [4], considering the obstacle with the contacts on its sidewalls in the circular waveguide with $\mathrm{TE}_{01}$ mode, it was shown that $E_{\varphi}$ is the major electric field component in the SE. The same peculiarity is characteristic of the obstacle in the cylindrical waveguide with $\mathrm{TE}_{11}$ mode.

For an obstacle placed at $\varphi=90^{\circ}$ the dependences of the resonance position on the electrophysical parameters of it are the same as for the obstacle in the waveguide with $\mathrm{TE}_{01}$ mode presented in [4]. As usual, an increase of length $l$ leads to a shift of resonance position to a lower frequency, and an increase of specific conductivity causes a decrease of electric field strength in the SE. An increase of $h$ leads to a shift of resonance to a lower frequency while an increase of width $d$ does not influence much the position of resonance.

We performed additional simulations to elucidate the dependence of position of the polarization plane of in- cident wave, in respect to the centre of SE, on the resonance position and amplitude. Results of the simulation are shown in Fig. 2(a). It is seen that a clear resonance was obtained at $13.1 \mathrm{GHz}$. The amplitude of the electric field decreases when the polarization plane approaches the SE. Averaged in the azimuthal direction distribution of the electric field at $\varphi=90^{\circ}$ is shown in Fig. 2(b). It is seen that the half wave resonance in the wave propagation direction is excited in the structure.

In the configuration investigated here, semiconductor is surrounded by three metal interfaces (two contacts and a wall of the waveguide). Thus, zero tangential electric field boundary condition on the third interface strongly influences the electric field distribution in the SE.

It is worth noting that the position of the resonance can be easily shifted in the frequency scale by changing either the length or the height of the SE while, by changing the specific resistance, the average electric field in the SE can be adjusted. The general scheme of optimization has been based on two issues: (i) by changing the dimensions of SE the resonance is put in a "right" place in a frequency scale, (ii) by changing the specific resistance of SE the desirable value of $\eta$ is achieved.

\subsection{Frequency response optimization}

During our investigation, two possible scenarios for optimizing the sensor were considered. First, short sensors $(l=0.3-0.4 \mathrm{~mm})$ were investigated since they should not distort too much the electric field in the waveguide. By changing the specific resistance of SE, it should be possible to employ the interplay between con- 
(a)

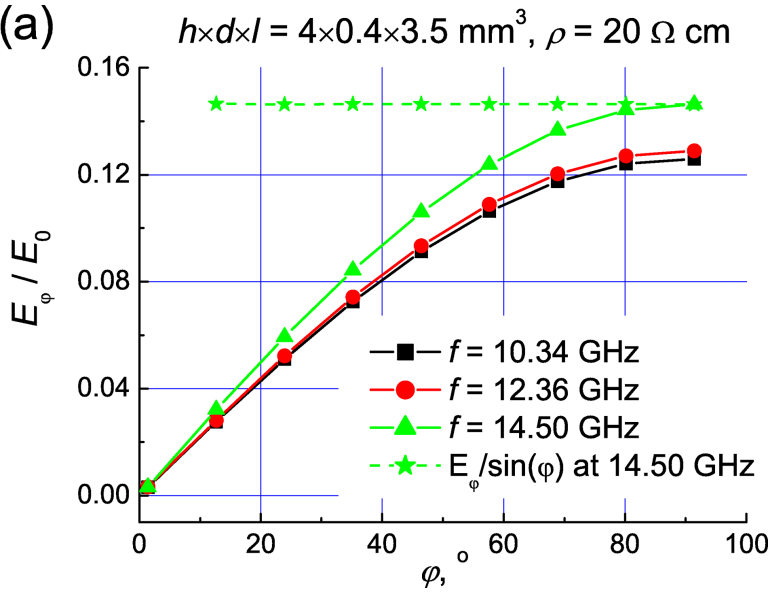

(b)

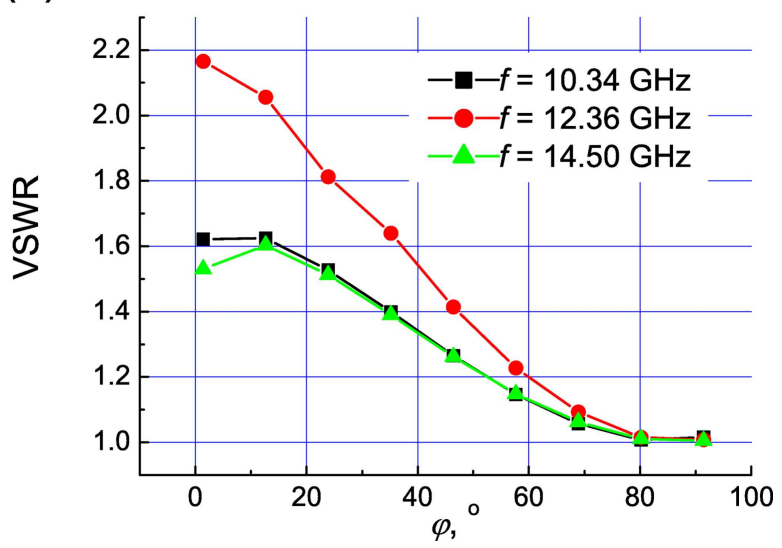

Fig. 3. Dependences of (a) the average electric field within the sensor and (b) VSWR on the angle between centre of the SE and polarization plane of the incident wave for several frequencies. The ratio $E_{\varphi} / \sin \varphi$ is also plotted in (a) for $f=14.5 \mathrm{GHz}$.

duction and displacement currents for obtaining the desirable electric field increase with frequency. Results of these simulations show that it is possible to get electric field ratio $\eta$ close to the desired value 1.23 and simultaneously lower than $50 \Omega$ resistance, however some practical problem appears. For such a sensor we found that small change of $d$ leads to a substantial increase of the ratio $\eta$. Therefore, the practical realization of the sensor could face some difficulties due to unintentional size and positioning variations.

In addition to the investigated short sensors, we also performed series of calculations for fixed width $d=$ $1.77 \mathrm{~mm}$ and height $h=2 \mathrm{~mm}$ but increasing the length of the SE in a wave propagation direction $l$. Unfortunately, the increase of $l$ leads to the monotonous decrease of the electric field ratio $\eta$ for considered specific resistances. Such results indicate that the larger sensors should be investigated due to two reasons: (i) once the length and/or height of the SE is increased, a lower resistance is obtained, (ii) the larger size of SE enhances the possibilities to exploit electric field increase near the resonant frequency.

Results of the simulation for $d=1.57 \mathrm{~mm}$ SE show that the increased height $(h=4 \mathrm{~mm})$ and length $(l=$ 3-7 mm) leads to the increase of $\eta$. This is an indication that higher sensors become "massive" enough to have resonant frequency near the end of the investigated frequency range providing a more suitable dependence of the electric field on frequency. Another favourable feature of this layout becomes noticeable when exploring ratios $\eta$ for fixed $l$ and various $d$ values. Electric field at higher frequency tends to grow faster once the width $d$ is reduced. This feature is particularly important, since reduced width can potentially decrease the reflection coefficient from the sensor. It should also be emphasized that $\eta$ changes smoothly once the dimensions are changing within $0.5 \mathrm{~mm}$ and therefore such a sensor should be more suitable from practical point of view.

\subsection{Properties of optimal sensor}

We calculated the parameter $\eta$ for different size and specific resistance sensing elements. Results of simulation show that the SE with dimensions $h \times d \times l=$ $4 \times 0.4 \times 3.5 \mathrm{~mm}^{3}, \rho=20 \Omega \mathrm{cm}, R=5.6 \Omega$ has the value of $\eta$ close to 1.23. Therefore such sensor has been selected for a more detailed investigation. Dependences of the average electric field and voltage standing wave ratio on polarization angle for three frequencies are presented in Fig. 3. From Fig. 3(a) it follows that the angular dependence of the average electric field in the SE at $14.5 \mathrm{GHz}$ almost perfectly matches the $\sin \varphi$ dependence that is characteristic of the regular $E_{\varphi}$ component of the incident $\mathrm{TE}_{11}$ wave. It seems that similar angular dependence is typical of the other frequencies as well. Such property can be attributed to the geometry of the SE. It is thin in $\varphi$ direction and its metal contacts are perpendicular to the $E_{\varphi}$ component. It is seen that the SE perfectly detects the maximum of the $E_{\varphi}$ amplitude $\left(\varphi=90^{\circ}\right)$ at every frequency, therefore such device can act as a nearly perfect sensor for the measurement of a local $E_{\varphi}$ value. Unfortunately, metal contacts perpendicular to the walls of the waveguide introduce substantial reflections once the SE is placed in the position where $E_{r}$ value is at its maximum. As follows from Fig. 3(b), the VSWR increases substantially for small $\varphi$, reaching almost the value of 2.2 when the $\mathrm{SE}$ is placed in the position $\varphi=0^{\circ}$.

Once the electric field strength in the SE is determined, the dependence of relative resistance change on 

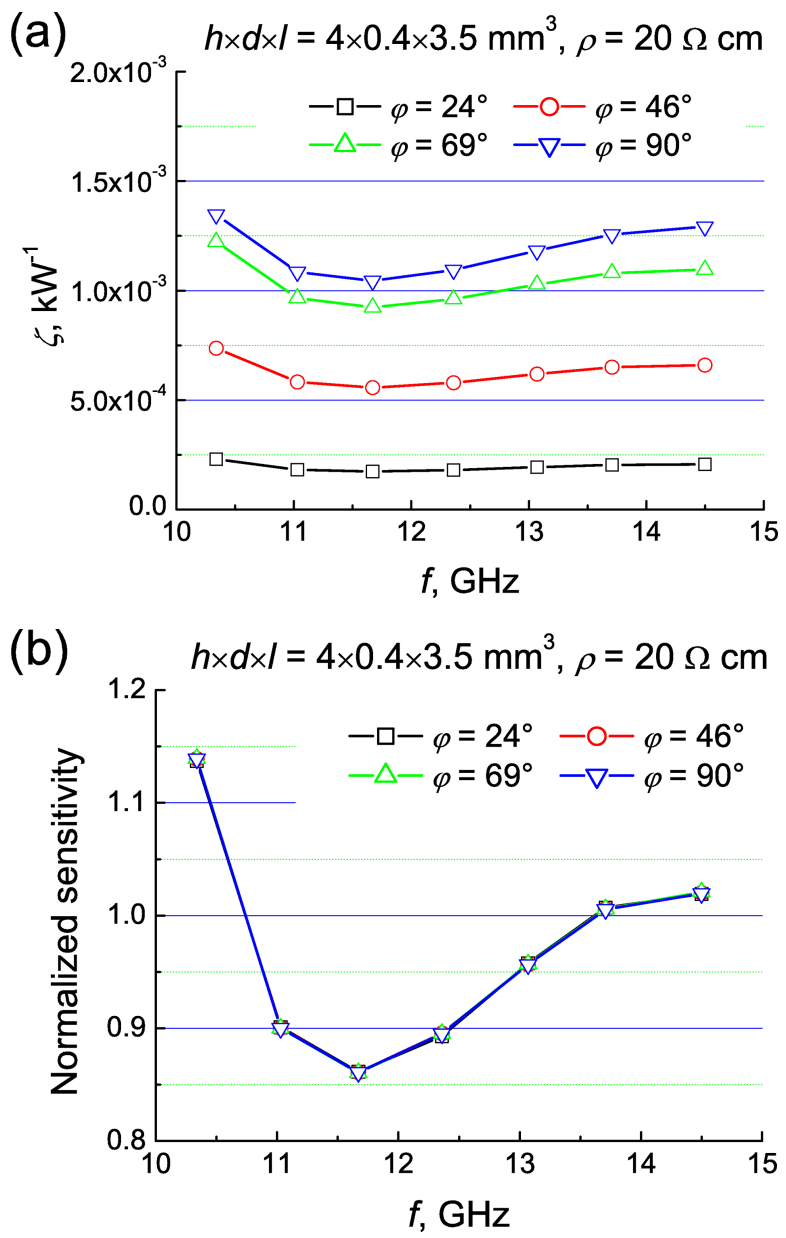

Fig. 4. Dependences of (a) sensitivity and (b) normalized sensitivity on frequency for the optimal sensor for a few polarization angles indicated in the figure. In (b) the sensitivity is normalized to the average of minimum and maximum values in the considered frequency

range. It remains nearly the same within $1.2 \%$ for all angles.

power transmitted through the waveguide can be calculated. Calculation results are shown in Fig. 5 by a solid line. Dotted line corresponds to the linear dependence of $\Delta R / R$ on $P$ that is characteristic of the warm electron region. It is seen that at a maximum power roughly $35 \%$ relative resistance change of the SE is observed. Due to a small width of the optimal SE, the average electric field in it consists of $E_{\varphi}$ component only. The amplitude of the component $E_{r}$ is roughly $10^{-4}$ and $E_{z}$ is even smaller.

Therefore for the practical application the current sensor should be rotatable, enabling one to place it in the position perpendicular to the polarization plane of the incident wave. As follows from Fig. 3(b), the reflection from the SE can also indicate the desirable position of the SE in respect of polarization plane. At $\varphi=90^{\circ}$ VSWR is at its minimum.

An extensive investigation has been performed to reveal more details of the dependence of sensitivity on

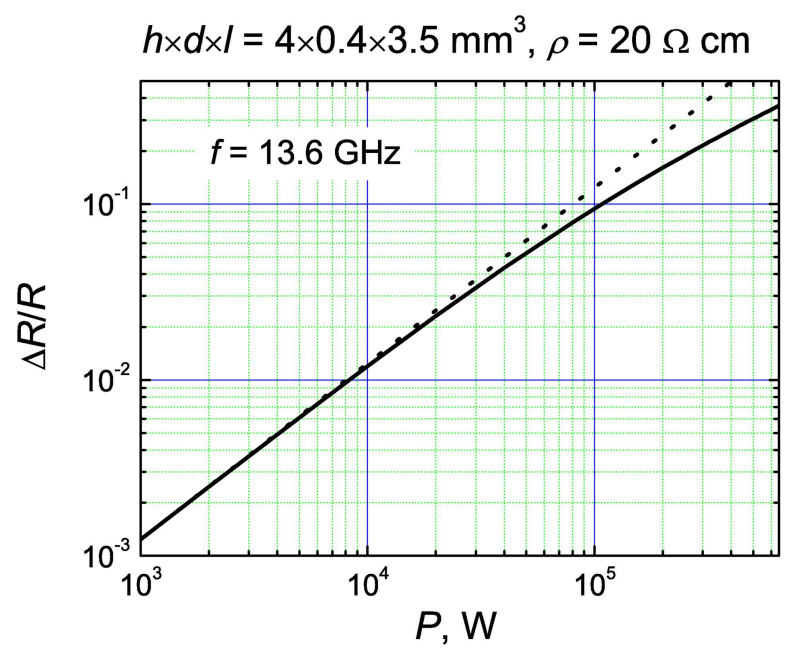

Fig. 5. Calculated dependence of the relative resistance change of the optimal RS on power transmitted through the waveguide at $f=$ 13.6 GHz. Solid line shows results calculated using (10), dotted line corresponds to the linear dependence.

frequency. Results of the simulation are presented in Fig. 4. As it can be expected, the sensitivity increases with the increase of the angle $\varphi$. It was already mentioned that an increase of the angle leads to a growth of the component $E_{\varphi}$ of the incident wave near the SE. Unfortunately, the absolute value of sensitivity varies within $\pm 14 \%$ over the entire frequency range. However, normalized sensitivity remains the same within $1.2 \%$ for every fixed frequency, confirming that this device can be of some use as nearly the ideal sensor for a fixed frequency to determine the position of the polarization plane in the waveguide.

Distributions of the electric field components in the waveguide section with the SE are shown in Fig. 6. The distribution of the components $E_{\varphi}$ (Fig. 6(a,d)), $E_{r}$ (Fig. 6(b)), and $E_{z}$ (Fig. 6(c)) in different $\varphi 0 z$ planes are presented. It is seen that due to a small width of SE, the perturbation of regular components of $\mathrm{TE}_{11}$ wave at $\varphi=90^{\circ}$ is small (Fig. 6(a,b)). VSWR for this particular case is roughly 1.02. Some perturbation of the regular wave is seen in the planes close to the SE. The component $E_{z}$ that is absent in the regular wave is excited but its amplitude is very small - less than $1 \%-$ in the centre of the waveguide. It becomes more significant in the obstacle or near it. The distribution of electric field changes significantly when the position of the SE coincides with polarization plane (Fig. 6(d)). Partly standing wave between the SE and the excitation plane appears demonstrating strong reflection from the SE. VSWR for this particular case is roughly 1.6. 
(a) $f=10.3 \mathrm{GHz}, 90^{\circ}$
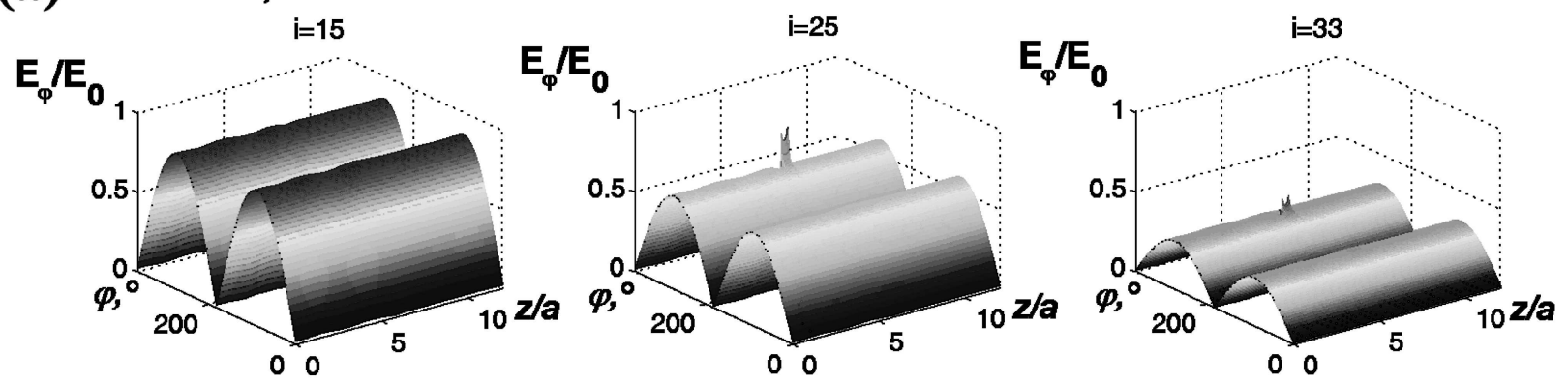

(b) $\mathrm{f}=10.3 \mathrm{GHz}, 90^{\circ}$
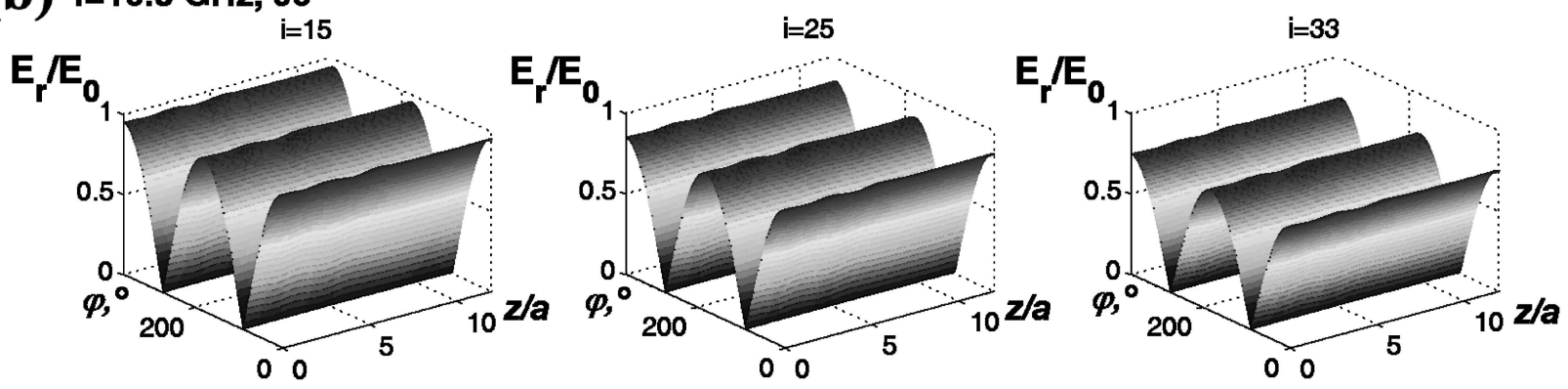

(c) $\mathrm{f}=10.3 \mathrm{GHz}, 90^{\circ}$
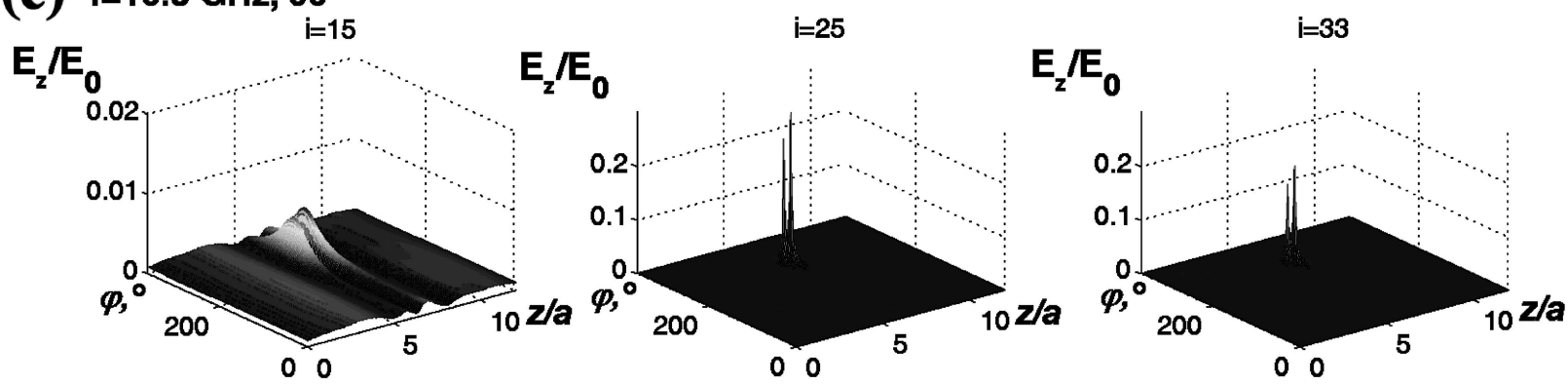

(d) $\mathrm{f}=10.3 \mathrm{GHz}, 0^{\circ}$
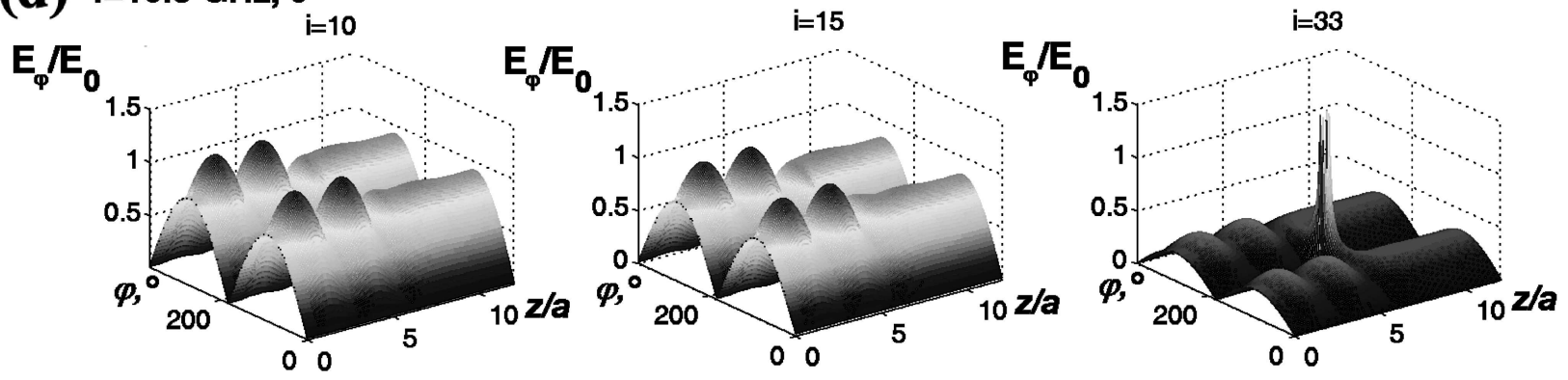

Fig. 6. Distributions of the components of electric field in the waveguide with the SE on the different surfaces $\varphi 0 z$ at $f=10.3 \mathrm{GHz}: E_{\varphi}$ at (a) $\varphi=90^{\circ}$ and (d) $\varphi=0^{\circ}$ for $r=(i-1) \Delta r$; (b) $E_{r}$ at $\varphi=90^{\circ}$ for $r=(i-0.5) \Delta r$; (c) $E_{z}$ at $\varphi=90^{\circ}$ for $r=(i-0.5) \Delta r$. Calculation parameters: $\Delta r=0.025, \Delta z=0.05, \Delta \varphi=2.8^{\circ}, \Delta t=6.10 \cdot 10^{-4}$. Dimensions of the SE are $h \times d \times l=4.0 \times 0.4 \times 3.55 \mathrm{~mm}^{3}$, 


\section{Conclusions}

Two possible scenarios for obtaining a nearly flat frequency response of the sensor were considered. One possibility is to build a very short, narrow, and relatively high sensor. However, in this case its sensitivity is very susceptible to small changes of dimensions. Another possibility is a narrow plate shaped sensor. The optimal SE found at a moment should have the following parameters: $h \times d \times l=4 \times 0.4 \times 3.5 \mathrm{~mm}^{3}, \rho=$ $20 \Omega \mathrm{cm}, R=5.6 \Omega$. Such sensor retains the dependence of its normalized sensitivity on frequency for a changing angle between the sensor's position and polarization plane of the incident wave, but the sensitivity changes quite substantially $( \pm 14 \%$ of the average value) in the frequency range of $10.3-14.5 \mathrm{GHz}$. Therefore, such sensor should be more applicable for fixed frequency but variable polarization experiments.

\section{Acknowledgement}

Effort sponsored by the Air Force Office of Scientific Research, Air Force Material Command, USAF, under grant number FA8655-07-1-3028.

\section{References}

[1] M. Dagys, Ž. Kancleris, R. Simniškis, E. Schamiloglu, and F.J. Agee, Resistive sensor: Device for high-power microwave pulse measurement, IEEE Antenn. Propag. Mag. 43(5), 64-79 (2001).

[2] M.B. Goykhman, N.F. Kovalev, N.G. Kolganov, and A.V. Palitsin, Measurement of high-power microwave pulses by resistive hot-electron sensors, Techn. Phys. Lett. 30(6), 500-502 (2004).

[3] Ž. Kancleris, G. Šlekas, V. Tamošiūnas, R. Simniškis, P. Ragulis, and M. Tamošiūnienè, Semiconductor plate interacting with $\mathrm{TE}_{01}$ mode in circular waveguide, Lithuanian J. Phys. 49(1), 35-43 (2009).

[4] Ž. Kancleris, G. Šlekas, V. Tamošiūnas, and M. Tamošiūnienè, Resistive sensor for high power microwave pulse measurement of $\mathrm{TE}_{01}$ mode in circular waveguide, Progr. Electromagn. Res. PIER 92, 267-280 (2009).

[5] S. I. Baskakov, Basics of Electrodynamics (Moscow, Sov. Radio, 1973) [in Russian].

[6] A.M. Perez, V.E. Boria, B. Gimeno, S. Anza, C. Vicente, and J. Gil, Multipactor analysis in circular waveguides, J. Electromagn. Waves Appl. 23(11-12), 1575-1583 (2009) .

[7] M. Thumm and H. Kumric, High-power $\mathrm{TE}_{11}$ and $\mathrm{TM}_{11}$ circular polarizers in oversized waveguides at $70 \mathrm{GHz}$, Int. J. Infrared Millimet. Waves 10(9), 10591075 (1989).

[8] T. Kamei, Frequency performance for $\mathrm{TE}_{11}$ circular waveguide filters, IEICE Trans. Electron. E85-C(8), 1634-1641 (2002).

[9] I. Bogdankevich, I. Ivanov, O. Loza, P. Strelkov, D. Ulyanov, and E. Garate, A high power (50 MW), broadband $(50 \%)$ plasma-aided microwave amplifier, in: 28th ICPIG, July 15-20, 2007, Prague, Czech Republic, 1194-1197 (2007).

[10] R.W. Scharstein and A.T. Adams, Thick circular iris in a $\mathrm{TE}_{11}$-mode circular waveguide, IEEE Trans. Microw. Theor. Tech. 36(11), 1529-1531 (1988).

[11] QuinStar Technology, QCW Series Circular Waveguide Sections and Flanges, www.quinstar.com/ qcw_circular_waveguide_sections_and_flanges.html .

[12] A. Taflove and S.C. Hagness, Computational Electrodynamics: The Finite-Difference Time-Domain Method, 2nd ed. (Artech House, Norwood, MA, 2000).

[13] Ž. Kancleris, Handling of singularity in finitedifference time-domain procedure for solving Maxwell's equations in cylindrical coordinate system, IEEE Trans. Antenn. Propag. 56(2), 610-613 (2008). 


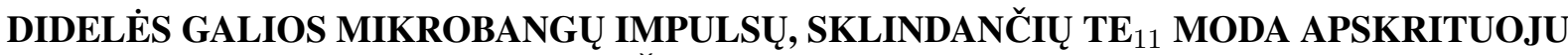 BANGOLAIDŽIU, REZISTORINIS JUTIKLIS
}

\author{
Ž. Kancleris ${ }^{a, b}$, G. Šlekas ${ }^{a}$, V. Tamošiūnas ${ }^{a, b}$, M. Tamošiūniené ${ }^{a}$, M. Dagys ${ }^{a}$

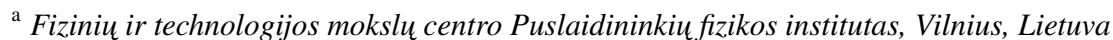 \\ ${ }^{\mathrm{b}}$ Vilniaus universiteto Fizikos fakultetas, Vilnius, Lietuva
}

\section{Santrauka}

Apžvelgti darbai, kuriuose naudojami apskritieji bangolaidžiai su jais sklindančia $\mathrm{TE}_{11}$ moda. Pateikti rezistorinio jutiklio (RJ), skirto didelès galios mikrobangų impulsų matavimui, privalumai lyginant juos su puslaidininkiniais diodais. Nagrinejjama galimybẻ sukurti RJ, skirtą $\mathrm{TE}_{11}$ modos, sklindančios apskrituoju bangolaidžiu, didelès galios mikrobangų impulsams matuoti. RJ jautrusis elementas (JE), kurį sudaro iš $n$-Si pagamintas tūrinis bandinys, yra patalpintas ant apskritojo bangolaidžio sienelès. Metaliniai kontaktai suformuoti ant šoninių jutiklio plokštumų. Suformuluoti reikalavimai jutiklio JE: jutiklis turi nesukelti žymesnių atspindžių bangolaidyje (stovinčios bangos koeficientas $<1,2$ ), minimali jutiklio išvado signalo dažninė priklausomybẻ - užtikrinti galimybę matuoti nanosekundinès trukmès impulsus (JE varža negali viršyti $50 \Omega$ ). Ištirta JE sąveika su $\mathrm{TE}_{11}$ modos elektromagnetine banga apskritajame bangolaidyje plačiame dažnių intervale. Skaičiavimai atlikti naudojant baigtinių skirtumų laiko skalejje metodą. Ieškant optimalių JE parametrų skaičiuota elektrinio lauko pasiskirstymas, stovinčiosios bangos koeficientas ir vidutinio elektrinio lauko priklausomybès nuo dažnio kelioms skirtingų matmenų ir savitosios varžos RJ jautriujuc elementų serijoms.

Tyrimų rezultatai atskleidè kelius optimalaus RJ kūrimui. Pirmiausia buvo išnagrinèta galimybẻ sukurti trumpa RJ, kurio ilgis $l=0,3-0,4 \mathrm{~mm}$, aukštis $h=2 \mathrm{~mm}$, nes toks jutiklis mažiau iškraipytu elektrini lauką bangolaidyje. Skaičiavimo rezultatai parodè, kad įmanoma sukurti trumpą RJ, kuris atitiktu visus jam keliamus reikalavimus, tačiau nustatyta, kad, net nežymiai pakeitus tokio RJ jautriojo elemento ploti $d$, gali žymiai pakisti elektrinių laukų santykis. Dèl šios priežasties galètų kilti sunkumu gaminant RJ, todèl buvo išnagrinèta galimybè sukurti ilgesni jutikli $(l=3-7 \mathrm{~mm})$. Tačiau (pasirinktoms JE medžiagos savitosios varžoms $\rho$ ) buvo stebimas tik monotoniškas elektrinių laukų santykio mažejimas, kai JE aukštis buvo $h=2 \mathrm{~mm}$. Išnagrinèjus RJ su aukštesniais JE ( $h=$ $4 \mathrm{~mm}$ ), buvo nustatyti optimalūs JE matmenys bei savitoji varža $\left(h \times d \times l=4 \times 0,4 \times 3,5 \mathrm{~mm}^{3}, \rho=20 \Omega\right)$. Apskaičiuotos vidutinio elektrinio lauko optimaliojo RJ viduje ir stovinčiosios bangos koeficiento priklausomybės nuo kampo tarp jutiklio JE ir krintančios bangos poliarizacijos plokštumos, esant skirtingiems elektromagnetinès bangos dažniams, bei jautrio priklausomybès nuo dažnio, kai skyrèsi poliarizacijos kampai. Taip pat buvo apskaičiuotos optimaliojo RJ santykinès varžos pokyčio priklausomybès nuo bangolaidžiu sklindančios galios ir elektrinio lauko sandų pasiskirstymas bangolaidyje su JE. Skaičiavimo rezultatai parodè, kad pasirinktas optimalusis RJ labiau tinka naudoti eksperimentuose, kai elektromagnetinès bangos dažnis pastovus, bet gali būti naudojamas poliarizacijos tyrimams. 